\title{
Effect of recombinant human erythropoietin and doxorubicin in combination on the proliferation of MCF-7 and MDA-MB231 breast cancer cells
}

\author{
ESAM M. RADWAN ${ }^{1}$, RASEDEE ABDULLAH ${ }^{2}$, MOTHANNA SADIQ AL-QUBAISI ${ }^{2}$, \\ MOHAMED E. EL ZOWALATY ${ }^{3}$, SEÏF-EDDINE NAADJA ${ }^{4}$, \\ NOORJAHAN B. ALITHEEN ${ }^{4}$ and ABDUL-RAHMAN OMAR ${ }^{1,2}$ \\ ${ }^{1}$ Department of Veterinary Laboratory Diagnosis, Faculty of Veterinary Medicine; \\ ${ }^{2}$ Laboratory of Vaccines and Immunotherapeutics, Institute of Bioscience, University Putra Malaysia, \\ Serdang, Selangor 43400, Malaysia; ${ }^{3}$ Biomedical Research Center, Qatar University, Doha 2713, Qatar; \\ ${ }^{4}$ Faculty of Biotechnology and Biomolecular Sciences, University Putra Malaysia, Serdang, Selangor 43400, Malaysia
}

Received March 8, 2015; Accepted August 19, 2015

DOI: $10.3892 / \mathrm{mmr} .2016 .4989$

\begin{abstract}
Patients with cancer often exhibit signs of anemia as the result of the disease. Thus, cancer chemotherapies often include erythropoietin (EPO) in the regime to improve the survival rate of these patients. The aim of the present study was to determine the effect of EPO on doxorubicin-treated breast cancer cells. The cytotoxicity of doxorubicin alone or in combination with EPO against the MCF-7 and MDA-MB-231 human breast cancer cells were determined using an MTT cell viability assay, neutral red (NR) uptake assay and lactate dehydrogenase (LDH) assay. The estimated half maximal inhibitory concentration values for doxorubicin and the combination of doxorubicin with EPO were between 0.140 and $0.260 \mu \mathrm{g} / \mathrm{ml}$ for all cells treated for $72 \mathrm{~h}$. Treatment with doxorubicin in combination with EPO led to no notable difference in cytotoxicity, compared with treatment with doxorubicin alone. The antiproliferative effect of doxorubicin at a concentration of $1 \mu \mathrm{g} / \mathrm{ml}$ on the MDA-MB-231 cells was demonstrated by the decrease in viable cells from $3.6 \times 10^{5}$ at $24 \mathrm{~h}$ to $2.1 \times 10^{5}$ at $72 \mathrm{~h}$ of treatment. In order to confirm apoptosis in the doxorubicin-treated cells, the activities of caspases-3/7 and -9 were determined using a TBE assay. The results indicated that the activities of caspases-3/7 and -9 were significantly elevated in the doxorubicin-treated MDA-MB-231 cells by 571 and $645 \%$, respectively, and in the MCF 7 cells by 471 and $345 \%$, respectively, compared with the control cells. EPO did not modify the effect of
\end{abstract}

Correspondence to: Professor Rasedee Abdullah, Laboratory of Vaccines and Immunotherapeutics, Institute of Bioscience, University Putra Malaysia, Serdang, Selangor 43400, Malaysia E-mail: rasedee@upm.edu.my

Key words: erythropoietin, doxorubicin, proliferation, MCF-7, MDA-MB231, breast cancer doxorubicin on these cell lines. The results of the present study suggested that EPO was safe for use in combination with doxorubicin in the treatment of patients with breast cancer and concurrent anemia.

\section{Introduction}

Patients with cancer often develop anemia as a result of the complex interaction of various factors, which renders treatment of the disease somewhat unpredictable $(1,2)$. Among the factors contributing to anemia include hemodilution, bleeding, hypersplenism and hemophagocytosis, hemolysis, nutritional deficiencies, bone marrow damage, chemotherapy, radiotherapy and the anemia of the cancer itself (3-6). One of the causes of anemia in these patients may be due to the frequently lower than expected levels of circulating erythropoietin (EPO) for the degree of anemia (7-9).

EPO is a heavily glycosylated glycoprotein produced in the peritubular cells of the kidneys in response to hypoxia (10) and is vital as a hematopoietic hormone regulating erythrocyte production. The hormone binds to the EPO receptor to cause proliferation, differentiation and survival of erythoid progenitors. Each EPO binds to two EPO receptors on the erythroid cell surface to cause an effect (11-13).

Doxorubicin is the optimal known systemic chemotherapy, which may be used alone or in combination with a variety of agents, including, epirubicin, mitoxantrone, cisplatin and etoposide, in the treatment of breast cancer $(14,15)$. However, doxorubicin frequently induces anemia in patients with breast cancer $(16,17)$ by causing systemic changes, primarily through hemolysis or other conditions that reduce hemoglobin concentration (18-20). In patients with breast cancer, the management of anemia is beneficial for improvement of the survival rates of these patients.

Previously, EPO was found not to interfere with tamoxifen or Taxol in the treatment of MCF-7 or MDA-MB231 cells (21). Whether EPO can similarly affect the efficacy of doxorubicin in the treatment of breast cancer remains to be elucidated. 
Therefore, the present study investigated the effect of EPO treatment in combination with doxorubicin on MDA-MB231 and MCF-7 cells. The present study also examined the mechanism underlying the cytotoxicity of this combination in these cancer cell lines. The present study aims to improve cancer therapeutics and provide potential insights to possible application of the recombinant human erythropoietin and doxorubicin combination in cancer therapy.

\section{Materials and methods}

Cell culture. The three cell lines used in the present study were obtained from American Type Culture Collection (Rockville, MD, USA). These cell lines comprised the estrogen receptor-positive $\mathrm{MCF}-7$ and estrogen receptor-negative MDA-MB-231 human breast cancer lines, and the normal MCF-10A breast cell line, which were characterized to be virus negative. These cells grow as an adherent monolayer of tightly knit epithelial cells.

Cytotoxicity MTT assay. The MCF-7, MDA-MB 231 and MCF-10A cells were seeded at $1 \times 10^{4}$ cells/well by adding $200 \mu \mathrm{l}$ of a $5 \times 10^{4}$ cells $/ \mathrm{ml}$ suspension to each well of a 96 -well tissue culture plate. The cells were cultured at $37^{\circ} \mathrm{C}$ for $24 \mathrm{~h}$ in the presence of $5 \% \mathrm{CO}_{2}$ until cell density of $50 \%$ confluence was obtained. The cells were then treated with either $1 \mu \mathrm{g} / \mathrm{ml}$ doxorubicin (Sigma-Aldrich, St. Louis, MO, USA), 1 IU EPO (Sigma-Aldrich) or a combination of $1 \mu \mathrm{g} / \mathrm{ml}$ doxorubicin and $1 \mathrm{IU}$ EPO. Following $72 \mathrm{~h}$ incubation at $37^{\circ} \mathrm{C}, 20 \mu \mathrm{l} \mathrm{MTT}$ solution (Sigma-Aldrich; $5 \mathrm{mg} / \mathrm{ml}$ ) was added to each well and the plates were re-incubated for $4 \mathrm{~h}$ at $37^{\circ} \mathrm{C}$. The microplates were swiftly turned to discard the medium and the formazan precipitate was dissolved in dimethyl sulfoxide (100\%; Ajax Finechem PTY Ltd., Sydney, Australia). The microplates were then gently agitated in the dark for $30 \mathrm{~min}$ and the absorbance was determined using a microtiter plate reader at 570 and $630 \mathrm{~nm}$ for background (Model 550; Bio-Rad Laboratories, Inc., Hercules, CA, USA). All experiments were performed in triplicate. The half maximal inhibitory concentration $\left(\mathrm{IC}_{50}\right)$ was determined from dose-response curves constructed for each cell line.

Neutral red (NR) uptake. The cells were seeded at $1 \times 10^{4}$ cells/well into 96-well plates until they reached $40-60 \%$ confluence, and were subsequently incubated overnight at $37^{\circ} \mathrm{C}$ in the presence of $5 \% \mathrm{CO}_{2}$ for cell attachment. After $24 \mathrm{~h}$, the medium was removed and replaced with $200 \mu \mathrm{l}$ fresh growth medium, containing either $1 \mu \mathrm{g} / \mathrm{ml}$ doxorubicin, 1 IU EPO or a combination of $1 \mu \mathrm{g} / \mathrm{ml}$ doxorubicin and $1 \mathrm{IU}$ EPO. The plates were incubated at $37^{\circ} \mathrm{C}$, in $5 \% \mathrm{CO}_{2}$ for $72 \mathrm{~h}$, following which the cells were washed three times with $200 \mu \mathrm{l}$ phosphate-buffered saline (PBS) followed by the addition of $200 \mu 1$ NR solution (Sigma-Aldrich). The cells were then incubated for $3 \mathrm{~h}$ at $25^{\circ} \mathrm{C}$. The NR solution was removed and the cells were exposed to fixing solution (Promega Corporation, Madison, WI, USA; $1 \% \mathrm{CaCl}_{2}$ and $0.5 \%$ formaldehyde in milliQ water) for 1-2 min, followed by two washing steps. The washing solution (Promega Corporation) consisted of $1 \%$ acetic acid and 50\% ethanol in milliQ water. Following the second wash, the plates were incubated for $10 \mathrm{~min}$, following which the plates were read using a microplate reader at $540 \mathrm{~nm}$. A control experiment was performed on untreated cells under the same conditions. The intensity of NR staining was directly proportional to the number of viable cells.

Lactate dehydrogenase ( $L D H$ ) assay. To determine the effect of doxorubicin on the membrane permeability of MCF-7 and MDA MB231 cells, an LDH release assay was used. The cells were seeded in 96-well culture plates at a density of $2 \times 10^{4}$ cells/well in $100 \mu \mathrm{l}$ and allowed to grow for $18 \mathrm{~h}$ prior to treatment. Treatments were performed, as described above for the MTT assay. Following incubation for $72 \mathrm{~h}, 40 \mu \mathrm{l}$ of the supernatants were removed and placed in a fresh 96 -well for the determination of $\mathrm{LDH}$ release. The original plate was replenished with $40 \mu \mathrm{l} 6 \%$ Triton X-100 (Sigma-Aldrich) for determination of the total $\mathrm{LDH}$ concentration. An aliquot of $100 \mu 14.6 \mathrm{mM}$ pyruvic acid (Sigma-Aldrich) in $0.1 \mathrm{M}$ potassium phosphate buffer ( $\mathrm{pH} 7.5$; Sigma-Aldrich) was dispensed into each well of the plate containing the supernatant only, and was mixed via repeated pipetting. Subsequently, $100 \mu \mathrm{l}$ of $0.4 \mathrm{mg} / \mathrm{ml}$ reduced $\beta$-NADH (Sigma-Aldrich) in $0.1 \mathrm{M}$ potassium phosphate buffer ( $\mathrm{pH}$ 7.5) was added to the wells, and the kinetic change, based on the loss of NADH due to its oxidation to $\mathrm{NAD}^{+}$as pyruvate is converted into lactate, was determined. The change in absorbance at $340 \mathrm{~nm}$ was read for 1 min using an ELISA microplate reader (Model 550). This procedure was repeated using $40 \mu \mathrm{l}$ of the total cell lysate from the original plate containing cells to determine the total LDH concentration. A change of 0.001 absorbance $\mathrm{U} / \mathrm{min}$ was equivalent to $1 \mathrm{U} / 1$ of $\mathrm{LDH}$ activity (22). The percentage of $\mathrm{LDH}$ release was determined by dividing the $\mathrm{LDH}$ released in the supernatant by the total $\mathrm{LDH}$ in the respective cell lysate. Untreated cells retained $\mathrm{LDH}$ and exhibited minimal loss over the time.

Trypan blue exclusion. The MCF-7 and MDA MB231 cells were first seeded at $1 \times 10^{4}$ cells/well into 6-well plates until they reached $40-60 \%$ confluence. Following $24 \mathrm{~h}$ of incubation to allow for cell attachment, the cells were exposed to $1 \mu \mathrm{g} / \mathrm{ml}$ doxorubicin or a combination of $1 \mu \mathrm{g} / \mathrm{ml}$ doxorubicin and $1 \mathrm{IU}$ EPO. The plates were then incubated at $37^{\circ} \mathrm{C}$ in $5 \%$ $\mathrm{CO}_{2}$ for 24,48 and $72 \mathrm{~h}$. Following incubation, the media was removed and the cells washed with cold PBS to remove dead cells. Subsequently, $1 \mathrm{ml} 0.05 \%(2 \mathrm{mg} / \mathrm{ml})$ trypsin-EDTA (Invitrogen; Thermo Fisher Scientific, Inc., Waltham, MA, USA) was added to each well. The plates were re-incubated at $37^{\circ} \mathrm{C}$ for $10-15 \mathrm{~min}$, until the majority of the cells had detached. The cells were harvested, and the suspension was centrifuged at $2,000 \times \mathrm{g}$ for $10 \mathrm{~min}$ at $4^{\circ} \mathrm{C}$ and the supernatant discarded. The cell suspension $(20 \mu \mathrm{l})$ was mixed with $20 \mu 10.4 \%$ trypan blue solution (Sigma-Aldrich). The cells were re-suspended and dye-excluded viable cells were microscopically counted using a Neubauer hemocytometer (Hirschmann Laborgeräte GmbH and Co. KG, Eberstadt, Germany).

Microscopic examination of cell morphology. The MCF-7 and MDA MB231 cells $\left(1 \times 10^{4}\right.$ cells/well) were seeded into 6-well plates. Following incubation for $24 \mathrm{~h}$ with Dulbecco's modified Eagle's medium (Sigma-Aldrich), the cells were treated 
Table I. $\mathrm{IC}_{50}$ values of DOX-EPO treatment of breast cancer cells lines for $72 \mathrm{~h}$.

\begin{tabular}{lccr}
\hline & & $\mathrm{IC}_{50}(\mu \mathrm{g} / \mathrm{ml})$ & MCF-10a \\
\cline { 2 - 4 } Treatment & MCF-7 & MDA-MB231 & 0.149 \\
\hline DOX $(1 \mu \mathrm{g} / \mathrm{ml})$ & 0.217 & 0.121 & 0.145 \\
DOX-EPO $(1 \mu \mathrm{g} / \mathrm{ml}-1 \mathrm{IU} / \mathrm{ml})$ & 0.258 & 0.125 & \\
\hline
\end{tabular}

$\mathrm{IC}_{50}$, half maximal inhibitory concentration; DOX, doxorubicin; EPO, erythropoietin.

either with $1 \mu \mathrm{g} / \mathrm{ml}$ doxorubicin $(1 \mu \mathrm{g} / \mathrm{ml}), 1 \mathrm{IU} / \mathrm{ml}$ EPO or a combination of $1 \mu \mathrm{g} / \mathrm{ml}$ doxorubicin and $1 \mathrm{IU} / \mathrm{ml}$ EPO for $72 \mathrm{~h}$. The untreated cells were used as a negative control. General morphological and membrane changes were examined under an inverted microscope (CMM 214; Nikon Corporation, Tokyo, Japan).

Caspase-3/7 and -9 assays. The extent of caspases-3/7 and -9 activation in the MDA-MB231 and MCF-7 cells were treated using the same formulations in the assays described above, and were assessed using a commercially available colorimetric assay kit, according to the manufacturer's instructions (CaspACE ${ }^{\mathrm{TM}}$ assay system; Promega Corporation). The caspase activity in a sample is proportional to the quantity of para-nitroaniline (pNA) product detected spectrophotometrically (Lambda 35; PerkinElmer, Inc., Waltham, MA, USA). This assay uses the caspase-specific substrate L-asp artic-L-glutamic-L-valyl-L-aspartic acid para-nitroaniline (DEVD-pNA) and L-leucine-L-glutamyl-L-histidyl-L-asp artic-p-nitroaniline acid amide (LEHD-pNA), labeled with pNA for caspase-3/7 and-9, respectively. Cleavage of the substrate by the specific cellular caspase yields free pNA, which can be detected spectrophotometrically at $405 \mathrm{~nm}$. The cells were plated at a density of $1 \times 10^{6}$ cells/culture dish. Following treatment, the cells were harvested by centrifugation at 2,000 x g for $10 \mathrm{~min}$ at $4^{\circ} \mathrm{C}$. The pellets were washed with PBS and lysed in $50 \mu 1$ chilled cell lysis buffer (Promega Corporation) and maintained on ice for $10 \mathrm{~min}$. The lysate was centrifuged at $10,000 \mathrm{x}$ g for $1 \mathrm{~min}$ at $4^{\circ} \mathrm{C}$, and the supernatant was used to determine the caspase activities, which were measured colorimetrically at $405 \mathrm{~nm}$ by the production of pNA from the cleavage of DEVD-pNA and LEHD-pNA.

DNA fragmentation. DNA fragmentation was quantitatively determined using diphenylamine reagent. The cells were treated with doxorubicin alone or in combination with EPO at different time-points, and then harvested 12 and $24 \mathrm{~h}$ following treatment. Subsequently, $108 \mu \mathrm{l}$ of $5 \mathrm{M}$ perchloric acid (Sigma-Aldrich) was added to the samples, which were heated at $70^{\circ} \mathrm{C}$ for $15 \mathrm{~min}$, followed by the addition of two volumes of a solution containing diphenylamine reagent (Flinn Scientific, Batavia, IL, USA). The samples were stored at $4^{\circ} \mathrm{C}$ for $48 \mathrm{~h}$. The colorimetric reaction was quantified at $575 \mathrm{~nm}$ using an ultraviolet-visible thermo smart orbit spectrophotometer (PerkinElmer, Inc.). DNA from the pellet and supernatant were quantified. The degree of DNA fragmentation was determined according to the following equation: Degree of DNA fragmentation $=\left(\right.$ DNA $\left._{\text {supernatant }} / \mathrm{DNA}_{(\text {pellet+supernatant }}\right) \times 100 \%$ (1).
Table II. IC $_{50}$ values of DOX-EPO treatment of breast cancer cells lines for $72 \mathrm{~h}$, determined by neutral red exclusion assay.

\begin{tabular}{llc}
\hline & \multicolumn{2}{c}{$\mathrm{IC}_{50}(\mu \mathrm{g} / \mathrm{ml})$} \\
\cline { 2 - 3 } Treatment & MCF-7 & MDA-MB231 \\
\hline DOX $(1 \mu \mathrm{g} / \mathrm{ml})$ & 0.127 & 0.118 \\
DOX-EPO $(1 \mu \mathrm{g} / \mathrm{ml}-1 \mathrm{IU} / \mathrm{ml})$ & 0.143 & 0.120 \\
\hline
\end{tabular}

$\mathrm{IC}_{50}$, half maximal inhibitory concentration; DOX, doxorubicin; EPO, erythropoietin.

Statistical analysis. All experiments were completed in triplicate. The data were expressed as the mean \pm standard deviation and analyzed using Minitab statistical software (version 15; Minitab Inc., State College, PA, USA). Treatment effects were determined using one-way analysis of variance followed by Tukey's post hoc analysis. A value of $\mathrm{P}<0.05$ was considered to indicate a statistically significant difference.

\section{Results and Discussion}

Cell sensitivity to combination of doxorubicin and EPO. The present study determined the sensitivity of the MDA-MB-231, MCF-7 and MCF-10A cells to doxorubicin by evaluating their survival following exposure for $72 \mathrm{~h}$. Doxorubicin reduced the survival of all three cells in a dose-dependent manner (Fig. 1). Notably, the effect of doxorubicin was not selective towards breast cancer cells and also targeted the rapidly dividing normal cells. To investigate the effect of the combination treatment of doxorubicin and EPO, an equal combination of the two drugs were used. The combination treatment affected the cytotoxicity of doxorubicin. The estimated $\mathrm{IC}_{50}$ values for doxorubicin and the combination of doxorubicin with EPO were between 0.140 and $0.260 \mu \mathrm{g} / \mathrm{ml}$ following $72 \mathrm{~h}$ treatment (Tables I and II).

Lysosomal membrane activity. Lysosomes function as digestive system cells (23), where degrading enzymes are located (24). In the NR cell uptake assay, the uptake of dye is considered to occur by passive diffusion across the viable cell membrane through proton pumps $(25,26)$. The present study demonstrated that, in the MCF-7 cells, the lysosomal activity was proportionally lower, compared with the levels observed in the human breast cancer cells following treatment with doxorubicin or a combination of doxorubicin 

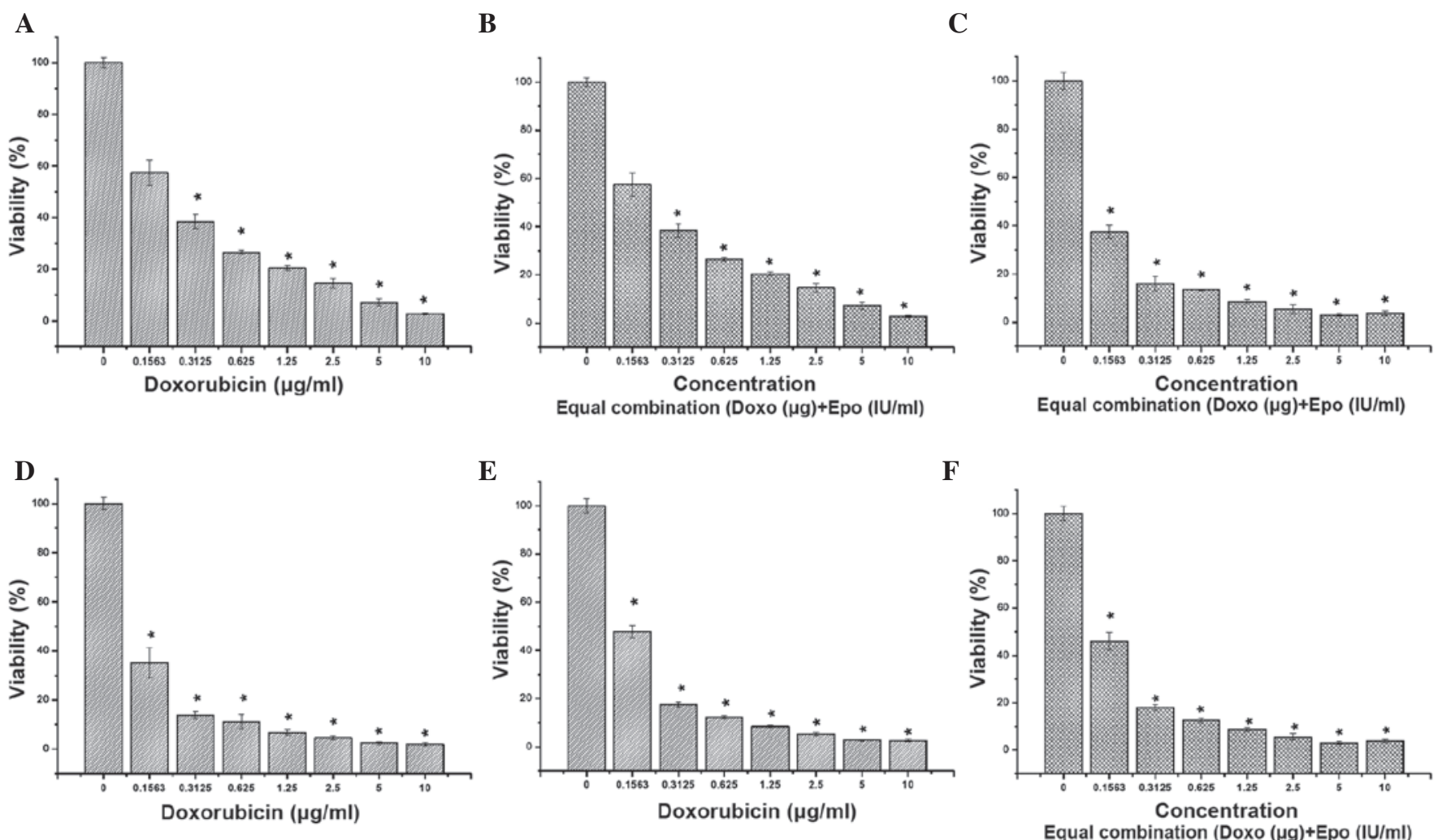

Figure 1. Treatment with Doxo, alone or combined with Epo decreases cell viability. Viability of the (A and B) MCF-7, (C and D) MDA-MB-231 and (E and F) MCF-10A cells after $72 \mathrm{~h}$ treatment with Doxo, alone or in combination with Epo. Data are expressed as the mean \pm standard deviation ( $\mathrm{n}=3$ wells/treatment). ${ }^{*} \mathrm{P}<0.05$, compared with the untreated cells. Doxo, doxorubicin; Epo, erythropoietin.

A

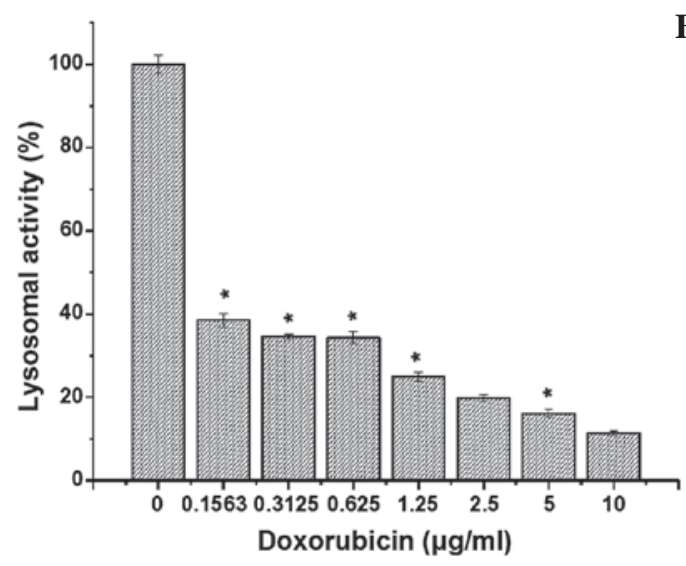

C

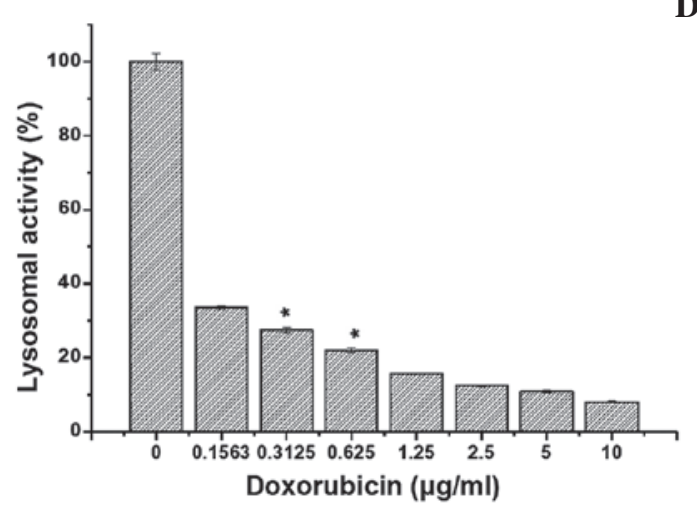

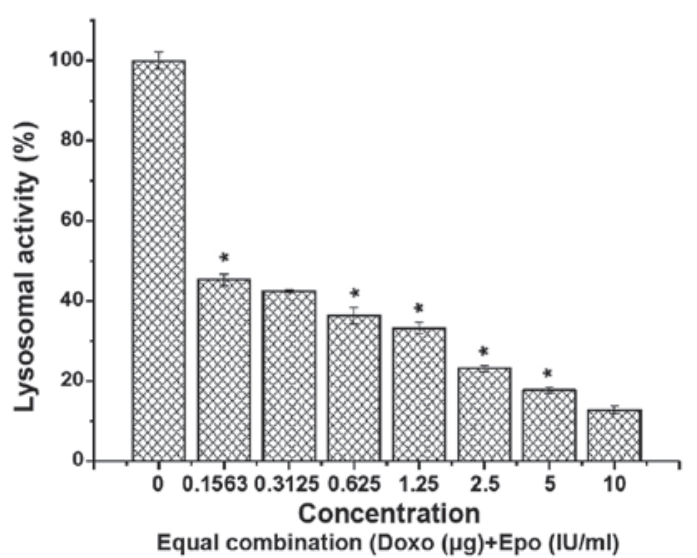

D

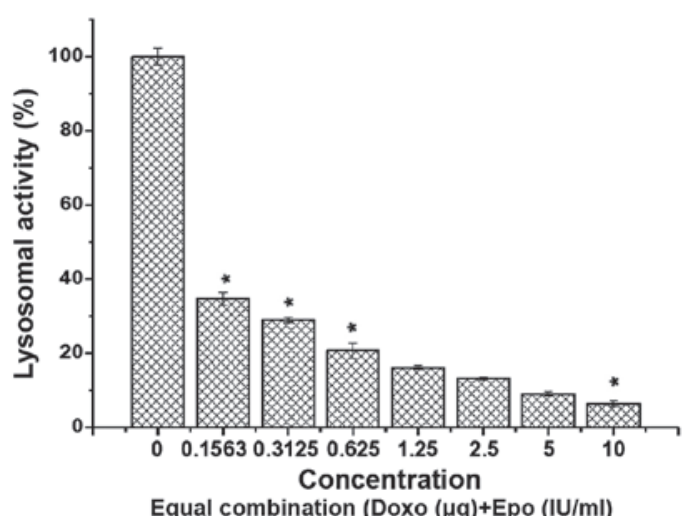

Figure 2. Treatment with Doxo, alone or combined with Epo decreases lysosomal activity. Lysosomal activity of the (A and B) MCF-7 and (C and D) MDA-MB-231 cells after $72 \mathrm{~h}$ treatment with Doxo, alone or in combination with Epo. Data are expressed as the mean \pm standard deviation ( $\mathrm{n}=3$ wells/treatment). $\mathrm{P}<0.05$, compared with the untreated cells. Doxo, doxorubicin; Epo, erythropoietin. 
A

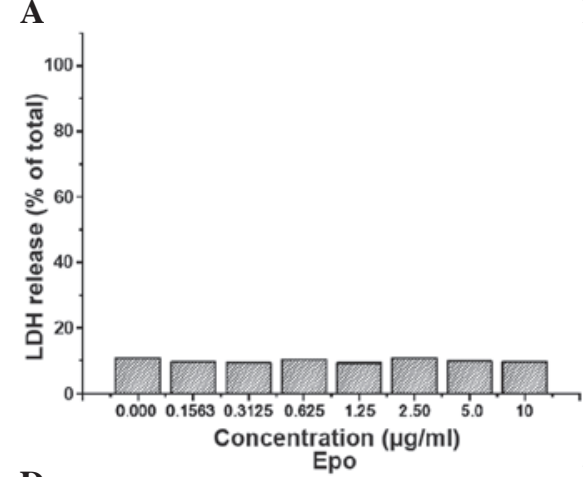

D

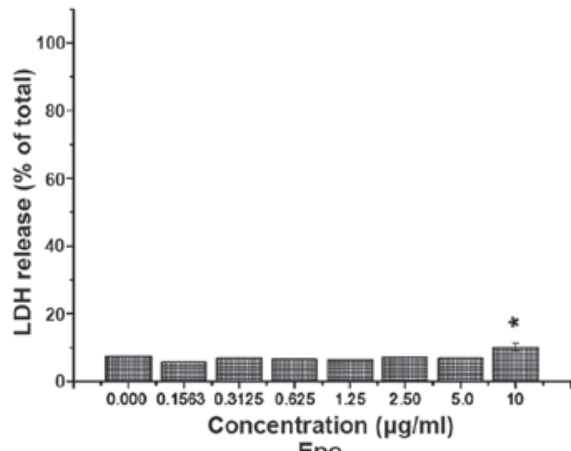

Epo
B

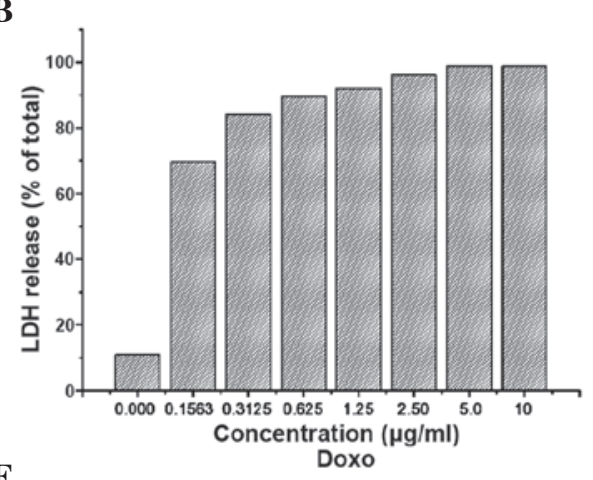

$\mathbf{E}$

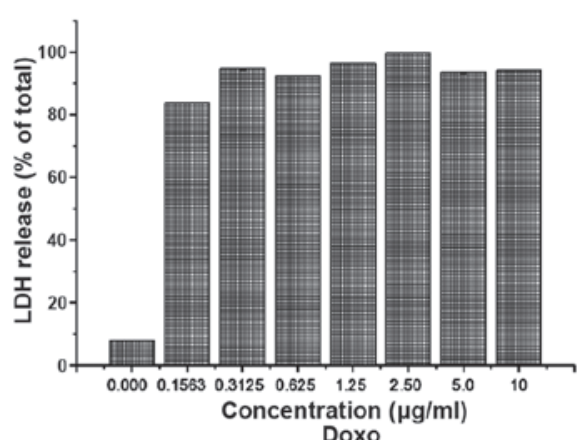

C

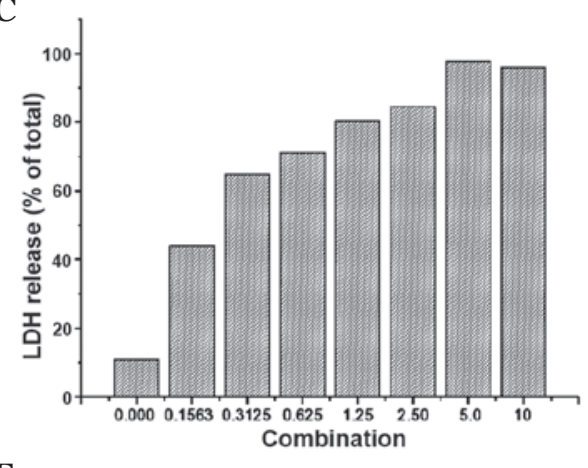

F

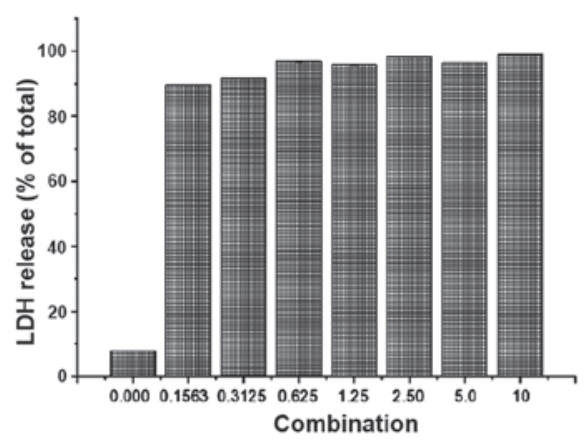

Figure 3. Treatment with Doxo, alone or combined with Epo increases LDH release. LDH release of the (A and B) MCF-7 and (C-F) MDA-MB-231 cells after $72 \mathrm{~h}$ treatment with Doxo, alone or in combination with Epo. Data are expressed as the mean \pm standard deviation ( $\mathrm{n}=3 \mathrm{wells} / \mathrm{treatment})$. $\mathrm{P}<0.05$, compared with the untreated cells. Doxo, doxorubicin; Epo, erythropoietin; LDH, lactate dehydrogenase.

A

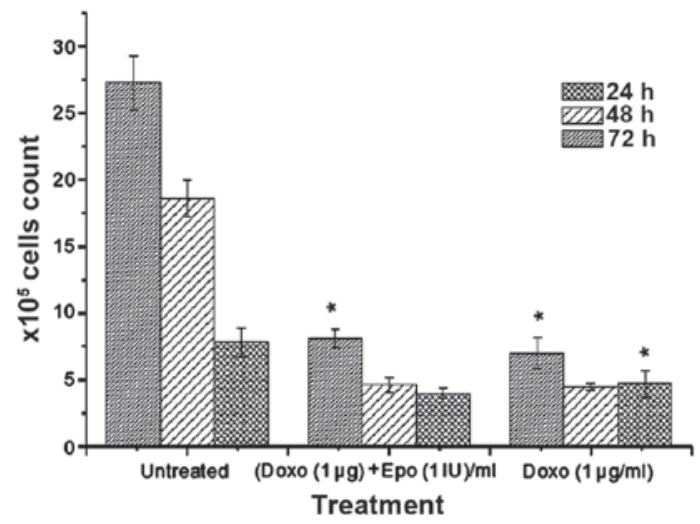

B

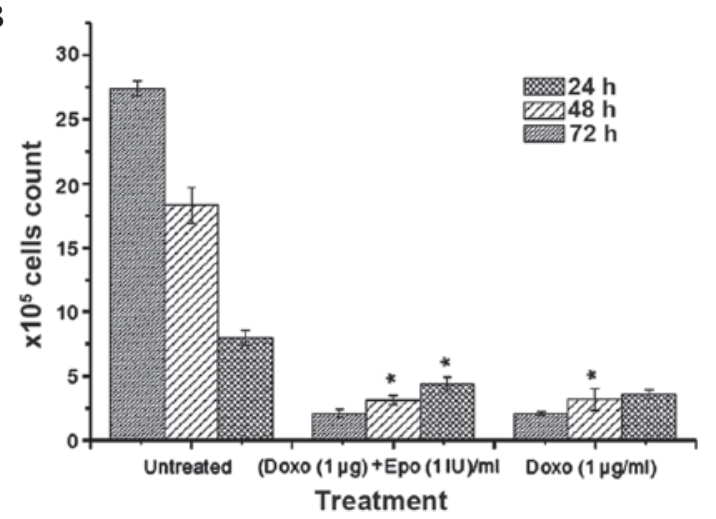

Figure 4. Treatment with Doxo, alone or combined with Epo has an antiproliferative effect. Antiproliferative effect of Doxo and Doxo-Epo combination on (A) MCF-7 and (B) MDA-MB231 cells. Data are expressed as the mean \pm standard deviation ( $\mathrm{n}=3$ wells/treatment). ${ }^{*}<<0.05$, compared with the untreated cells. Doxo, doxorubicin; Epo, erythropoietin.

and EPO. This suggested that certain cells that appeared viable may have lost the ability to accumulate the NR dye, possibly through the loss of lysosomal membrane stability (Fig. 2). However, in the MDA-MB-231 cells, this effect was not evident, suggesting that the effect of doxorubicin and its combination with EPO differed between these human breast cancer cell lines.

$L D H$ release. $\mathrm{LDH}$ is a leakage enzyme, which is released by dead cells. Thus, the measurement of LDH activity is another indicator of cell viability. As shown in Fig. 3, LDH release into the culture medium was examined following $72 \mathrm{~h}$ exposure to doxorubicin or the combination of doxorubicin with EPO.
The exposure of MCF-7 to $0.31 \mu \mathrm{g} / \mathrm{ml}$ doxorubicin increased LDH leakage by up to $84 \%$, compared with the increase of $68 \%$ observed following treatment with $0.15 \mu \mathrm{g} / \mathrm{ml}$ doxorubicin. However, increasing the doxorubicin concentration between 1.25 and $10 \mu \mathrm{g} / \mathrm{ml}$ caused only a marginal increase in LDH leakage, between 92 and 98\%. Following treatment with $0.15 \mu \mathrm{g} / \mathrm{ml}$ doxorubicin and $0.15 \mathrm{IU} / \mathrm{ml}$ EPO, MCF-7 cell death decreased by $43 \%$, which was lower than that observed in the Triton X-treated cells treated with $0.15 \mu \mathrm{g} / \mathrm{ml}$ doxorubicin (68\%). Therefore, the MDA-MB-231 cells were more sensitive to doxorubicin, compared with the MCF-7 cells. In the MDA-MB-231 cells, LDH leakage was $84 \%$ following treatment with $\sim 0.15 \mu \mathrm{g} / \mathrm{ml}$ doxorubicin for $72 \mathrm{~h}$, suggesting 

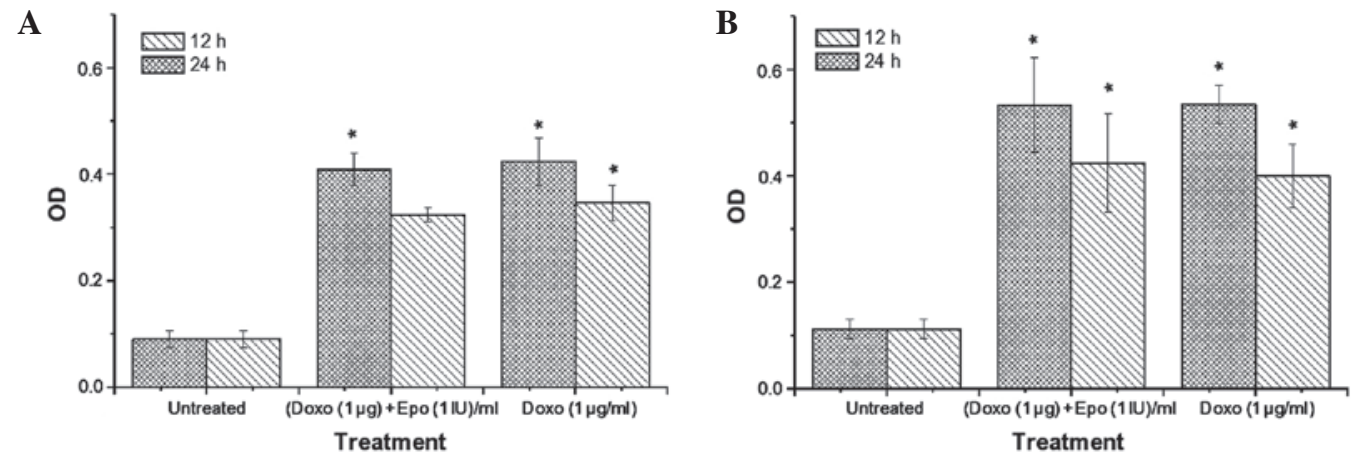

Figure 5. Treatment with Doxo, alone or combined with Epo increases the activity of caspase-3/7. Caspase-3/7 activity of the (A) MCF-7 and (B) MDA-MB231 cells following treatment with doxorubicin, alone or in combination with. Data are expressed as the mean \pm standard deviation ( $\mathrm{n}=3$ wells/treatment). ${ }^{*} \mathrm{P}<0.05$, compared with the untreated cells. Doxo, doxorubicin; Epo, erythropoietin; OD, optical density.
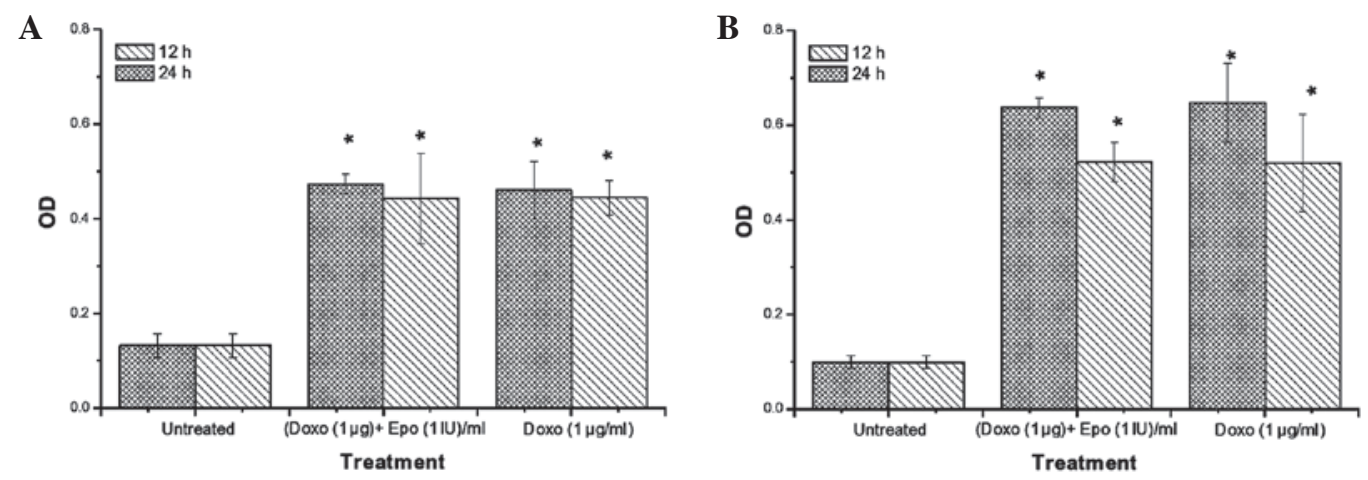

Figure 6. Treatment with Doxo, alone or combined with Epo increases the activity of caspase-9. Caspase-9 activity of the (A) MCF-7 and (B) MDA-MB231 cells following treatment with Doxo, alone or in combination with Epo. Data are expressed as the mean \pm standard deviation ( $\mathrm{n}=3$ wells/treatment). "P<0.05, compared with the untreated cells. Doxo, doxorubicin; Epo, erythropoietin; OD, optical density.

$\mathbf{A}$

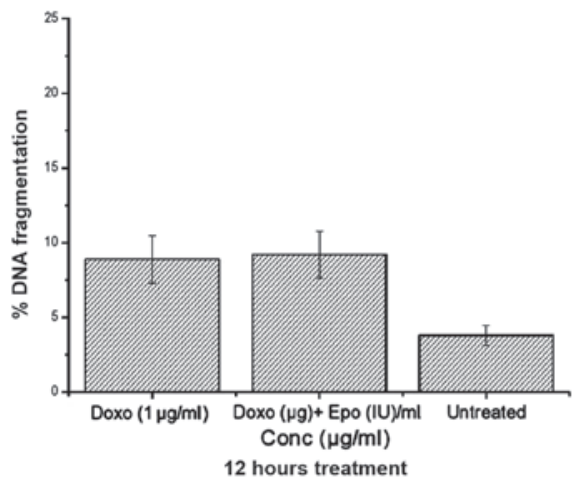

B

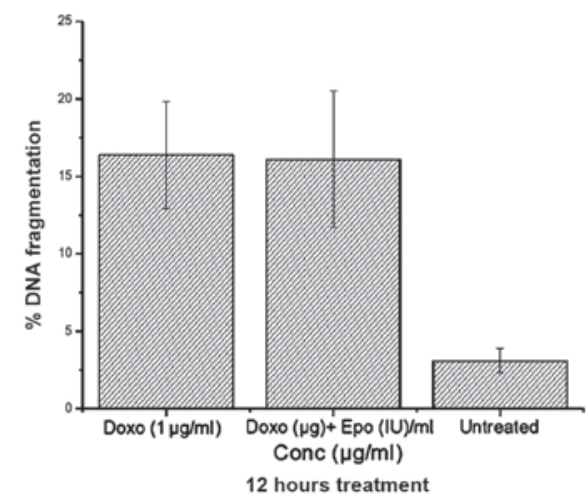

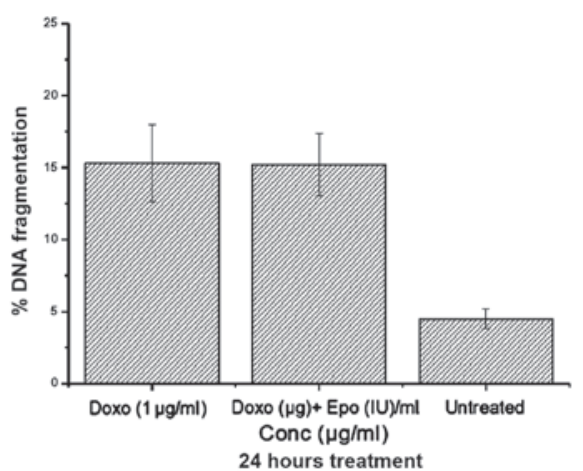

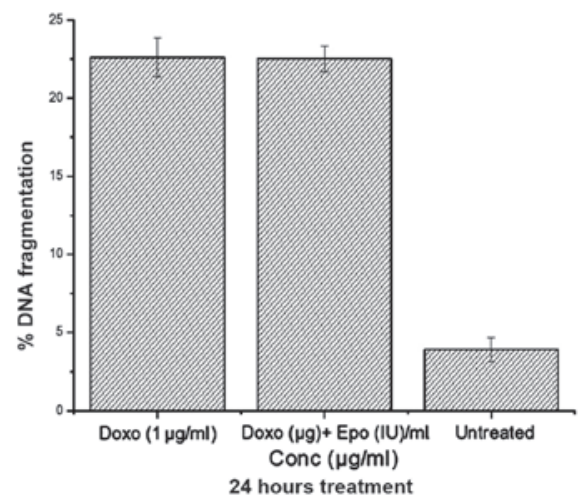

Figure 7. DNA fragmentation of the (A) MCF-7 and (B) MDA-MB231 cells treated with Doxo, alone or in combination with Epo. The percentages of DNA fragments are compared with the total DNA. Data are expressed as the mean \pm standard deviation ( $\mathrm{n}=3$ wells/treatment). Doxo, doxorubicin; Epo, erythropoietin. 

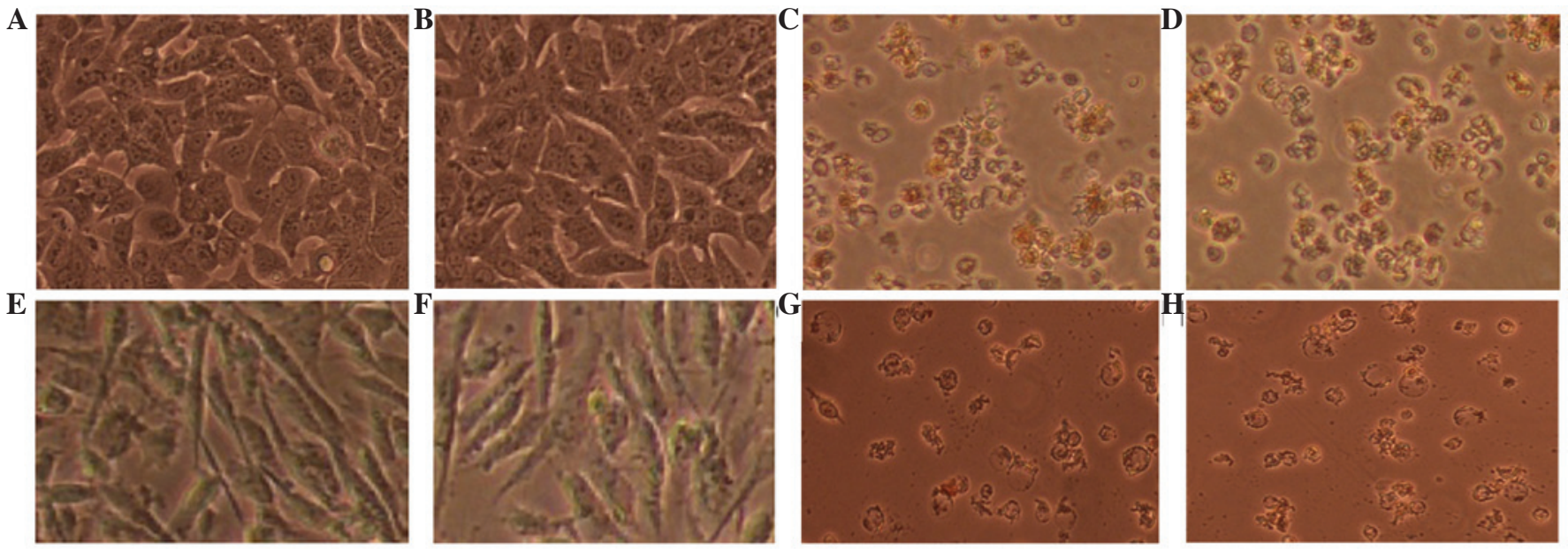

Figure 8. Photomicrographs (light microscopy; magnification, x200) showing morphological and growth inhibitory changes of (A-D) MCF-7 and (E-H) MDA-MB 231 cells following exposure to DOX, EPO or a combination of DOX and EPO for $72 \mathrm{~h}$. (A and E) Untreated cells; (B-D) EPO, DOX and combination treated MCF-7 cells; (F-H) EPO, DOX and combination treated MDA-MB 231 cells. EPO, erythropoietin; DOX, doxorubicin.

that this cell line was more sensitive to the cytotoxic effect of doxorubicin, compared with the MCF-7 cells. None of the concentrations of the doxorubicin-EPO combination treatment suppressed the cytotoxicity of doxorubicin alone in the MDA-MB-231 cell line.

Antiproliferation assay. The results of the antiproliferative effect of doxorubicin either alone or in a combination with EPO on the MCF-7 and MDA-MB-231 cells following 24, 48 and $72 \mathrm{~h}$ of incubation are shown in Fig. 4. Consistent with the findings from the MTT assay, the combination of doxorubicin and EPO was marginally less cytotoxic to the MCF-7 cells, compared with doxorubicin treatment alone. The results also demonstrated that the MDA-MB-231 cells were more sensitive to doxorubicin, compared with the MCF-7 cells. The viable cell counts for the untreated MDA-MB-231 following 24, 48 and $72 \mathrm{~h}$ incubation were 8.0, 18.3 and $27.4 \times 10^{5} / \mathrm{ml}$, respectively. As expected, the percentage survival of the doxorubicin-treated MDA-MB-231 cells decreased markedly with increase in exposure duration, which was in contrast to the untreated cells. The ratio of the viable cell to untreated cell counts at 24 and $72 \mathrm{~h}$ in the doxorubicin-EPO combination treatment group did not differ significantly to that in the doxorubicin alone treatment group.

Caspase-3/7 and -9 activities. Caspase-9 is an initiator of the mitochondria-mediated (intrinsic) apoptotic pathway (27), whereas caspase-3 is a major enzymatic marker of apoptosis (28). In the present study, the activities of caspase-3/7 (Fig. 5) and -9 (Fig. 6) increased significantly in the MCF-7 and MDA-MB-231 cells, compared with the untreated cells. Notably, the increase in caspase-3/7 activity appeared to be time-dependent. The highest caspase activities were observed in the MDA-MB-231 cells treated with doxorubicin. Doxorubicin-EPO combination treatment caused no significant difference in caspase activities, compared with the Dox alone group. After $24 \mathrm{~h}$, the activity of caspase-3/7 in the MDA-MB-231 were 571 and $476 \%$ higher, compared with the untreated cells following doxorubicin and doxorubicin-EPO combination treatments respectively. By contrast, the same treatments produced 471 and $571 \%$ increases in caspase-3/7 activities, respectively, in the MCF-7 cells. Doxorubicin and its combination with EPO appeared to induce a more marked increase in caspase-9 activity in the MDA-MB-231 cells, compared with the MCF-7 cells. Following treatment for $24 \mathrm{~h}$, the caspase activity in the MDA-MB-231 cells following doxorubicin and doxorubicin-EPO combination treatments were 645 and 635\% higher than in the untreated cells, whereas the activities of this enzyme were 345 and $356 \%$ for the respective treatments in the MCF-7 cells. These results suggested that EPO did not alter the stimulatory effect of doxorubicin on the activities of caspases-3/7 and -9 in the breast cancer cell lines.

DNA fragmentation. The relative quantity of small DNA fragments in the cells treated with $1 \mu \mathrm{g} / \mathrm{ml}$ doxorubicin is shown in Fig. 7. In the two breast cancer cell lines, doxorubicin treatment increased DNA fragmentation in a time-dependent manner. No difference in DNA fragmentation was observed between the cells treated with doxorubicin alone or with doxorubicin in combination with EPO, however, these treatments caused 338 and 573\% increases in DNA fragmentation in the MCF-7 and MDA-MB-231, respectively, compared with the untreated cells. These results suggested that doxorubicin was more sensitive to the estrogen-negative MDA-MB-231 cells than the estrogen-positive MCF-7 cells, and EPO did not modify the effect of doxorubicin.

Morphological alterations. The detachment of dead cells following exposure to doxorubicin was monitored using microscopic technique. Healthy cells remain elongated, whereas dying or dead cells are rounded and lose their adhesion to the culture plate. In the present study, inverse and fluorescence microscopy was performed following $72 \mathrm{~h}$ treatment of the MCF-7 and MDA MB231 cells with doxorubicin, which revealed marked morphological changes (Fig. 8). Cellular extensions were detected, cells were rounded and partially detached from the culture flask, and cellular membranes exhibited extensive blebbings.

Following $72 \mathrm{~h}$ incubation with $1.0 \mu \mathrm{g} / \mathrm{ml}$ doxorubicin and its combination with EPO, the majority of the adhered 
MCF-7 cells were spherical and exhibited a markedly different morphology. The morphological changes caused by doxorubicin in the MCF-7 cells included detachment and floating of the cells, the presence of shrunken and dispersed cells, and a reduction in the formation of a monolayer. After $72 \mathrm{~h}, 1 \mu \mathrm{g} / \mathrm{ml}$ doxorubicin caused substantial morphological changes when added to the MDA MB231 cells, with cells being detached, shrunken and dispersed, and membrane blebbing and cytoplasmic shrinkage observed. EPO (1 IU/ml) did not exhibit any changes in either of these cell lines. The above-mentioned changes were more apparent in the MDA MB231 cells, compared with the MCF-7 cells when subjected to the doxorubicin treatment for $72 \mathrm{~h}$.

The effect of doxorubicin or its combination with EPO were not selective for breast cancer cells as it also affected rapidly dividing normal breast cancer cells. However, the results of the cell viability investigations demonstrated that the MDA MB231 cells were more sensitive to the effect of doxorubicin or doxorubicin-EPO combination, compared with the MCF-7 cells. The results of the present study suggested that treatment with doxorubicin, either alone or in combination with EPO, induced apoptosis of the MCF-7 and MDA-MB-231 cells in a time-dependent manner, more through the caspase- 9 than the caspase- 3 pathway. This finding correlates with the observed increase in DNA fragmentation in the breast cancer cell lines following treatment. Of note, EPO did not modify the cytotoxicity of doxorubicin in the breast cancer cell lines, suggesting that these drugs can be safely used in combination in patients with breast cancer exhibiting symptoms of anemia.

\section{Acknowledgements}

The authors would like to thank the Institute of Bioscience and the University Putra Malaysia (Serdang, Malaysia) for supporting the present study.

\section{References}

1. Barrett-Lee P, Bokemeyer C, Gascón P, Nortier JW, Schneider M, Schrijvers D and Van Belle S; ECAS Advisory Board and Participating Centers: Management of cancer-related anemia in patients with breast or gynecologic cancer: New insights based on results from the European Cancer Anemia Survey. Oncologist 10: 743-757 2005.

2. Cella D: The functional assessment of cancer therapy-Anemia (FACT-An) scale: A new tool for the assessment of outcomes in cancer anemia and fatigue. Semin Hematol 34 (3 Suppl 2): 13-19, 1997.

3. Mughal TI: Current and future use of hematopoietic growth factors in cancer medicine. Hematol Oncol 22: 121-134, 2004.

4. Beguin Y: Prediction of response to optimize outcome of treatment with erythropoietin. Semin Oncol 25 (Suppl 7): 27-34, 1998.

5. Beguin Y: Erythropoiesis and erythropoietin in multiple myeloma. Leuk Lymphoma 18: 413-421, 1995.

6. Beguin Y and Vanstraelen G: Prediction of response to recombinant human erythropoietin in the anemia of cancer. In: Recombinant Human Erythropoietin (rhEPO) in Clinical Oncology Nowrousian MR (ed). 2nd edition. Springer, New York, NY, pp541-582, 2008.

7. Leonard RC, Untch M and Von Koch F: Management of anaemia in patients with breast cancer: Role of epoetin. Ann Oncol 16: 817-824, 2005
8. Aapro M, Leonard RC, Barnadas A, Marangolo M, Untch M, Malamos N, Mayordomo J, Reichert D, Pedrini JL, Ukarma L et al: Effect of once-weekly epoetin beta on survival in patients with metastatic breast cancer receiving anthracycline-and/or taxane-based chemotherapy: Results of the breast cancer-anemia and the value of erythropoietin (BRAVE) study. J Clin Oncol 26: 592-598, 2008.

9. Seal S, Thompson D, Renwick A, Elliott A, Kelly P, Barfoot R, Chagtai T, Jayatilake H, Ahmed M, Spanova $\mathrm{K}$, et al: Truncating mutations in the Fanconi anemia J gene BRIP1 are low-penetrance breast cancer susceptibility alleles. Nat Genet 38: 1239-1241, 2006

10. Hale SA, Wong C and Lounsbury KM: Erythropoietin disrupts hypoxia-inducible factor signaling in ovarian cancer cells. Gynecol Oncol 100: 14-19, 2006.

11. Fisher JW: Erythropoietin: Physiology and pharmacology update. Exp Biol Med (Maywood) 228: 1-14, 2003.

12. Fu P and Arcasoy MO: Erythropoietin protects cardiac myocytes against anthracycline-induced apoptosis. Biochem Biophys Res Commun 354: 372-378, 2007.

13. Lappin TR, Maxwell AP and Johnston PG: EPO's alter ego: Erythropoietin has multiple actions. Stem Cells 20: 485-492, 2002.

14. Henderson IC, Berry DA, Demetri GD, Cirrincione CT, Goldstein LJ, Martino S, Ingle JN, Cooper MR, Hayes DF, Tkaczuk KH, et al: Improved outcomes from adding sequential paclitaxel but not from escalating Doxorubicin dose in an adjuvant chemotherapy regimen for patients with node-positive primary breast cancer. J Clin Oncol 21: 976-983, 2003.

15. Ayers M, Symmans WF, Stec J, Damokosh AI, Clark E, Hess K, Lecocke M, Metivier J, Booser D, Ibrahim N, et al: Gene expression profiles predict complete pathologic response to neoadjuvant paclitaxel and fluorouracil, doxorubicin and cyclophosphamide chemotherapy in breast cancer. J Clin Oncol 22: 2284-2293, 2004.

16. Kirshner J, Hatch M, Hennessy DD, Fridman M and Tannous RE: Anemia in stage II and III breast cancer patients treated with adjuvant doxorubicin and cyclophosphamide chemotherapy. Oncologist 9: 25-32, 2004.

17. Melichar B, Solichova D, Melicharova K, Cermanova M, Urminska $\mathrm{H}$ and Ryska A: Systemic immune activation, anemia and thrombocytosis in breast cancer patients treated by doxorubicin and paclitaxel. Pteridines 17: 107-114, 2006.

18. Shuai X, Ai H, Nasongkla N, Kim S and Gao J: Micellar carriers based on block copolymers of poly (epsilon-caprolactone) and poly (ethylene glycol) for doxorubicin delivery. J Control Release 98: 415-426, 2004.

19. Lewin SN, Mutch DG, Whitcomb BP, Liapis H and Herzog TJ: Three cases of hemolytic uremic syndrome in ovarian cancer patients treated with combination gemcitabine and pegylated liposomal doxorubicin. Gynecol Oncol 97: 228-233, 2005.

20. Kang KW, Chun MK, Kim O, Subedi RK, Ahn SG, Yoon JH and Choi HK: Doxorubicin-loaded solid lipid nanoparticles to overcome multidrug resistance in cancer therapy. Nanomedicine 6: 210-213, 2010.

21. Gewirtz DA, Di X, Walker TD and Sawyer ST: Erythropoietin fails to interfere with the antiproliferative and cytotoxic effects of antitumor drugs. Clin Cancer Res 12: 2232-2238, 2006.

22. Jemmerson R, Laplante B and Treeful A: Release of intact, monomeric cytochrome $\mathrm{c}$ from apoptotic and necrotic cells. Cell Death Differ 9: 538-548, 2002.

23. Novikoff AB: Lysosomes in the physiology and pathology of cells: contributions of staining methods. In: Ciba Foundation Symposium-Lysosomes. de Reuck AVS and Cameron MP (eds), pp36-77, 2008.

24. Bonifacino JS and Traub LM: Signals for sorting of transmembrane proteins to endosomes and lysosomes. Annu Rev Biochem 72: 395-447, 2003.

25. Lloyd JB: Lysosome membrane permeability: Implications for drug delivery. Adv Drug Deliv Rev 41: 189-200, 2000.

26. Macintyre AC and Cutler DJ: The potential role of lysosomes in tissue distribution of weak bases. Biopharm Drug Dispos 9: 513-526, 1988.

27. Dörrie J, Gerauer H, Wachter Y and Zunino SJ: Resveratrol induces extensive apoptosis by depolarizing mitochondrial membranes and activating caspase- 9 in acute lymphoblastic leukemia cells. Cancer Res 61: 4731-4739, 2001.

28. Porter AG and Jänicke RU: Emerging roles of caspase-3 in apoptosis. Cell Death Differ 6: 99-104, 1999. 